\title{
THE IMPACT OF THE LABOUR TAX BURDEN ON THE LIVING STANDARD OF THE INHABITANTS OF LATVIA
}

\author{
Anastasija Jersova ${ }^{1}$, Inta Kotane ${ }^{2}$ \\ ${ }^{1}$ Rezekne Academy of Technologies, Rezekne, Latvia, e-mail: jer.anastasija@gmail.com \\ ${ }^{2}$ Mg.oec., lecturer, researcher, Rezekne Academy of Technologies, Rezekne, Latvia, \\ e- mail: inta.kotane@rta.lv
}

Received: 11 June 2020 / Revised: 1 July 2020/ Accepted: 10 July 2020 /

Published: 30 November 2020

\begin{abstract}
The standard of living of the inhabitants of Latvia, especially in the context of material well-being or disposable income, is a guarantee that the inhabitants will be able to meet their basic needs, which are important for ensuring an adequate standard of living. Inhabitants ensure their material well-being mainly by working and receiving a net salary, which is paid after the calculation and deduction of labour taxes. However, the state is essentially the same inhabitant, which has its own basic needs, the financing of which requires income, which is mainly obtained after the collection of certain taxes, which accordingly reduces material well-being or disposable income of the inhabitants which is an essential component of the standard of living.

The goal of the research: to investigate the impact of the labour taxes on the standard of living of the inhabitants of Latvia. The research uses general scientific research methods: the method of monographic or descriptive research, the comparative analysis method, an expert survey, data grouping, and the graphical method. Authors of the paper believe that employees employed in Latvia should be encouraged to use the possibilities of gross salary relief, thus promoting the growth of their net salary. In order to raise the living standards of the inhabitants in the short and long term, the government of Latvia and local governments must emphasize their attention to the growth of the national economy. The government of Latvia and local governments must implement measures aimed at raising the long-term living standards of the population and gaining material benefits in the future.
\end{abstract}

Keywords: Standard of living, material well-being, tax system, labour taxes. JEL code: $H 24, I 31$.

\section{Introduction}

The standard of living of inhabitants of a particular country is defined as the degree of satisfaction of the material and cultural needs of the inhabitants (Bērzina et al., 2008), one of the most important aspects in the life of an individual (Varvazovska, Prasilova, 2015), which depends on such factors as income of the group of individuals, purchasing power of money, number and age of the group members, management skills and standard of living (Grēvina et al., 2000). A standard of living is the level of wealth, comfort, material goods, and necessities available to a certain socioeconomic class or a certain geographic area. The standard of living includes basic material factors such as income, gross domestic product (GDP), life expectancy, and 
economic opportunity (Investopedia.com, n.d.). Most of the time in an individual's life is devoted to increasing the material well-being. Apart from the economic indicators that characterize the standard of living, the individual's ability to shape his / her daily life in such a way that the set desires are ultimately achieved is also important (Commission for Strategic Analysis, 2006). Material well-being is the basis for being able to take advantage of all the opportunities that provide an interesting and saturated life, so work and salaries, which are a source of material well-being, play an important role in life (Anča et al., 2006).

Taxes are a component of state revenue that provides not only state budget revenue but also the well-being of the inhabitants and the national economic development index. Accordingly, by generating revenue, the government can ensure the country's economic growth and increase the standard of living of the inhabitants (Puzule, 2019). Determining the limit of the optimal tax rate remains relevant in all countries with a transition economy, as tax payment traditions are not developed and there is a tendency that the government only wants to supplement the state budget without considering that the application of excessive tax rates contributes to increasing tax evasion, which in turn reduces the amount of state budget revenue (Ketners, Titova, 2009).

The authors believe that the tax reforms implemented to increase state budget revenues result in an additional tax burden on the inhabitants, thus reducing their disposable income, which in the long run has an impact on the standard of living of the inhabitants.

The goal of the research: to find out the impact of the labour taxes on the standard of living of the inhabitants of Latvia.

Tasks of the research:

1. To study labour taxes and the procedure of their application in Latvia.

2. To assess the impact of the labour taxes on the standard of living of the inhabitants.

Period of the research: 2015-2019.

The research uses general scientific research methods: the method of monographic or descriptive research and the comparative analysis method, an expert survey, data grouping, and the graphical method.

\section{Standard of living of the inhabitants and labour taxes}

Quality of life may be understood in two different ways: 1) in a broad sense, 2) in a narrow sense. Quality of life analysed in a narrow sense is a subjective assessment of the standard of living. In a broad sense, however, it encompasses all living conditions, analysed using both an objective-type approach and a subjective-type approach (Winiarcyuk-Razniak, Razniak, 
2011). Nadirova and Aliyevb (2016), researching motivation to work, labour income taxes and life satisfaction in Hungary, Estonia, Continental Europe and the United States, concluded that 'Numerous theoretical and empirical studies have identified a negative relation between tax rates (marginal and average) and work activity. [...] Differences in the motivation to work and tax induced income changes are probably linked not only to the size of the labour income tax or to the characteristics of the labour market but also to other factors that have not yet been efficiently explored. Perhaps that people who are more balanced in their approach to life are both happier and take more leisure. But a more persuasive story is that motivation to work has started to decline in Western Europe, due to high levels of life satisfaction, while in Eastern Europe motivation to work has started to increase because of low levels of life satisfaction.'

Within the research, there was conducted a survey of experts, in which the experts evaluated the indicators characterizing the standard of living of the inhabitants according to their importance on a scale from 1 (the most important indicator or priority No. 1) to 5 (the least important indicator or priority No. 5). The experts were asked to evaluate in order of importance the following indicators characterizing the standard of living of the inhabitants: household disposable income, income inequality, poverty rate, GDP per capita and regional development index. The selection of industry experts was based on their level of education (experts A, B, C and D with a doctorate in economics, expert $\mathrm{E}$ with a master's degree in economics and experts $\mathrm{F}$ and $\mathrm{G}$ with a master's degree and professional secondary education in another field) and academic and/or professional work experience in the field of economics, which for all the experts exceeds 25 years. By occupation, the experts can be divided into several groups, i.e. the government of Latvia (experts A, B and E), the local government (experts $F$ and $G$ ) and the academic staff (experts $C$ and D).

The answers provided by the experts were evaluated according to the degree of agreement. In the case of direct parameter evaluation, the degree of expert agreement is evaluated by the concordance coefficient W, (Kendall, 1955) according to formula 1 :

$$
W=\frac{12 \sum_{i=1}^{n}\left\{\sum_{j=1}^{m} r_{i j}-\frac{1}{2} m(n+1)\right\}^{2}}{m^{2}\left(n^{3}-n\right)}
$$

where, W - Concordance coefficient

$\mathrm{n}$ - Number of the assessed factors

$\mathrm{m}$ - Number of experts

$\mathrm{r}_{\mathrm{ij}} \quad-\quad i$ object rank by the $j$ expert opinion 
The value of the concordance coefficient varies in the interval $0 \leq W \leq 1$, moreover, $\mathrm{W}=0$, if there is no correlation between the ranks, and $\mathrm{W}=1$, if all the experts have ranked the objects equally. A sufficient value of the concordance coefficient is assumed to be $\mathrm{W} \geq 0.50$ when the consensus of experts is high enough (Kendall, 1955).

The calculated concordance coefficient $\mathrm{W}=0.23$, which indicates that the experts do not agree on their opinions, however, the disposable income level of households stands out as the most important indicator when assessing the standard of living of the inhabitants. Paid work, for most of the inhabitants, is the main source of income or a guarantor of material wellbeing, but income earned within the employment is subject to labour taxes. However, the experts noted GDP per capita as the second most important indicator.

Taxes not only provide state budget revenue but also contribute to the well-being of the inhabitants and increase the national economic development index. Thus, by increasing revenues, the government can ensure the country's economic growth and increase the standard of living of the inhabitants (Puzule, 2019). An American scientist (Busler, 2013), studying tax policy, concluded that while the literature shows varying studies concerning the impact of tax policy, there is a gap when searching for an optimum policy.... Most countries have tried combinations of monetary and fiscal policies to encourage growth, but none seem to be working effectively. The solution may be to change income tax policy.

Labour taxes affect both labour demand and supply, as they change the employer's costs and the employee's net salaries. ... Labour taxes also affect the impact of other labour market and social regulations, such as minimum salaries, unemployment and social security, benefits, employment relationships, etc. [...] Labour taxes influence the decision to participate in the labour market.... Income taxes have a greater impact on labour than consumption and property taxes, savings and investment decisions, so by shifting the tax burden from income to consumption and property can be expected to have a positive effect on employment and economic growth (Ministry of Finance, 2017).

Mandatory state social insurance contributions are contributions to the special state budget account, which are intended for financing social insurance services in a case of social insurance event (Ketners, Titova, 2009). Mandatory state social insurance contributions ensure the maintenance and / or increase of the standard of living of the inhabitants, however, this goal is achieved only in the long run, in case one of the social insurance cases occurs.

In 2015-2019 the mandatory state social insurance contributions applicable to both employees and employers increased (iFinanses, 2019), thus promoting the growth of state budget income in the short term, but in 
the long run promoting greater support for the inhabitants of Latvia by payments from the state budget in a situation when a social insurance event occurs.

The Solidarity Tax was introduced with the aim of "reducing the tax regression for employees, domestic employees with a foreign employer, foreign employees with a foreign employer and the self-employed with a higher income level, while ensuring state basic and municipal budget revenues for increasing social protection and for financing the needs to reduce inequality, including the financing of health care services, as well as ensuring the revenues of the state pension special budget and appropriate savings in the funded pension capital or private pension fund of socially insured persons "(Solidarity Tax Law, 2015).

Jarockis (2015) considers that 'when assessing the introduction of a solidarity tax from the point of view of constitutional law, it should first be noted that although the tax is considered as a restriction of fundamental rights, its payment is in the interest of the society. It is aimed at promoting the general well-being of society. It also means being able to safeguard the general welfare interests of society, such as national defence, education, and health care.... This tax, like any other tax, will provide revenue to the state budget that can then be used to protect public welfare. Thus, the legitimate aim of the restriction of fundamental rights is to protect the welfare of the society'.

The personal income tax does not ensure an increase in the standard of living of the inhabitants in the future but ensures the state budget revenue.

Personal income tax has its own peculiarities, as it has a fixed tax rate, but at the same time, employees can benefit from the applicable benefits - the monthly non-taxable minimum, the benefit for dependents, the benefit for the disabled and the benefit for politically repressed persons (iFinanses, 2019).

Consequently, labour taxes - mandatory state social insurance contributions, solidarity tax and personal income tax - are calculated and deducted from the disposable income of the inhabitants of Latvia (within the framework of this research - from paid work). Mandatory state social insurance contributions and personal income tax are applied to all employees employed in Latvia. On the other hand, the solidarity tax is calculated only in case the object of mandatory state social insurance contributions has been exceeded.

\section{Assessment of the labour tax burden}

Researchers (Blundell et al., 2018) believe that "the tax and transfer system can be a very important bridge between family labour income and 
living standards, through taxes, work-contingent credits and social assistance transfers. Tax and transfer systems are typically quite nonlinear, especially at low-incomes, and this can lead to very different inferences about levels of household income inequality; and major reforms to these systems can and do have large effects on the income distribution".

The experts evaluated the measures implemented by the government of Latvia and local governments, the goal of which is to increase the standard of living of the inhabitants according to their significance and efficiency on a scale from 1 (most significant and effective measure or priority No.1) to 7 (least significant and effective measure or priority No.7). The results of the expert discussion are summarized in Table 1.

Table 1. Assessment of the measures implemented by the government of Latvia and local governments with the aim to increase the standard of the living of the inhabitants by the experts (calculations of the authors)

\begin{tabular}{|c|c|c|c|c|c|c|c|c|}
\hline \multirow{3}{*}{$\begin{array}{l}\text { Measures implemented by the } \\
\text { government of Latvia and local } \\
\text { governments }\end{array}$} & \multicolumn{7}{|c|}{ Experts } & \multirow{3}{*}{ 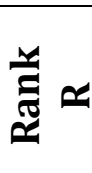 } \\
\hline & A & B & C & D & $\mathbf{E}$ & $\mathbf{F}$ & G & \\
\hline & \multicolumn{7}{|c|}{ Ratings } & \\
\hline $\begin{array}{l}\text { Reducing / increasing of the labour tax } \\
\text { burden }\end{array}$ & 6 & 3 & 1 & 6 & 5 & 2 & 4 & 3 \\
\hline Granting / increasing of social benefits & 5 & 4 & 4 & 5 & 7 & 7 & 7 & 7 \\
\hline $\begin{array}{l}\text { Setting / raising of the minimum monthly } \\
\text { salary }\end{array}$ & 7 & 6 & 7 & 4 & 2 & 5 & 6 & 6 \\
\hline Determination / increase of tax reliefs & 4 & 5 & 6 & 7 & 6 & 4 & 1 & 4.5 \\
\hline Access of education & 1 & 1 & 3 & 1 & 1 & 3 & 3 & 1 \\
\hline $\begin{array}{l}\text { Services, facilities and funding provided } \\
\text { by local governments }\end{array}$ & 3 & 7 & 5 & 3 & 4 & 6 & 5 & 4.5 \\
\hline Business support measures & 2 & 2 & 2 & 2 & 3 & 1 & 2 & 2 \\
\hline
\end{tabular}

The calculated concordance coefficient $\mathrm{W}=0.49$ indicates that the experts were generally united in their views and unanimously acknowledged the availability of education as the most important measure implemented by the government of Latvia and local governments with the aim to increase the standard of living of the inhabitants. The experts believe that regional schools should not be abolished, as this encourages residents to move to cities and promotes even greater depopulation of Latvia's countryside. Access to education gives people the opportunity to find a well-paid job in the future, and access to education is geared to long-term benefits. The experts assessed the reduction and increase of the labour tax burden as the third most important measure implemented by the government of Latvia and local governments with the aim to increase the standard of living of the 
inhabitants. Several experts acknowledge that tax reform (including increases in the minimum salary, changes in tax rates and incentives) can contribute to raising the standard of living of the inhabitants, especially household disposable income, but all these measures need to be considered within different groups of the inhabitants.

The average gross and net salaries and salaries of employees increased in 2015-2019. In 2019, compared with 2015, gross salaries and salaries increased by 251 EUR or $32.60 \%$, net salaries and salaries increased by 188 EUR or $32.75 \%$ and the labour tax burden increased by 63 EUR or $30.88 \%$. (Table 2)

Table 2. Average gross, net salary, and labour tax burden of employees in Latvia in 2015-2019, EUR (CSB database, 2020; calculations of the authors)

\begin{tabular}{|l|c|c|c|}
\hline & Gross salary & Net salary & Labour tax burden \\
\hline $\mathbf{2 0 1 5}$ & 778.00 & 574.00 & -204.00 \\
\hline $\mathbf{2 0 1 6}$ & 814.00 & 600.00 & -214.00 \\
\hline $\mathbf{2 0 1 7}$ & 877.00 & 642.00 & -235.00 \\
\hline $\mathbf{2 0 1 8}$ & 960.00 & 712.00 & -248.00 \\
\hline $\mathbf{2 0 1 9}$ & 1029.00 & 762.00 & -267.00 \\
\hline
\end{tabular}

In order to find out to what extent the labour tax burden affects the material well-being of the inhabitants (the amount of disposable income) or their standard of living, the calculation of employee X's net salary was performed, taking into account the following conditions: gross monthly salary 740 EUR; three dependent minors and since the 2017 the monthly non-permanent minimum has not been applied. (Fig.1)

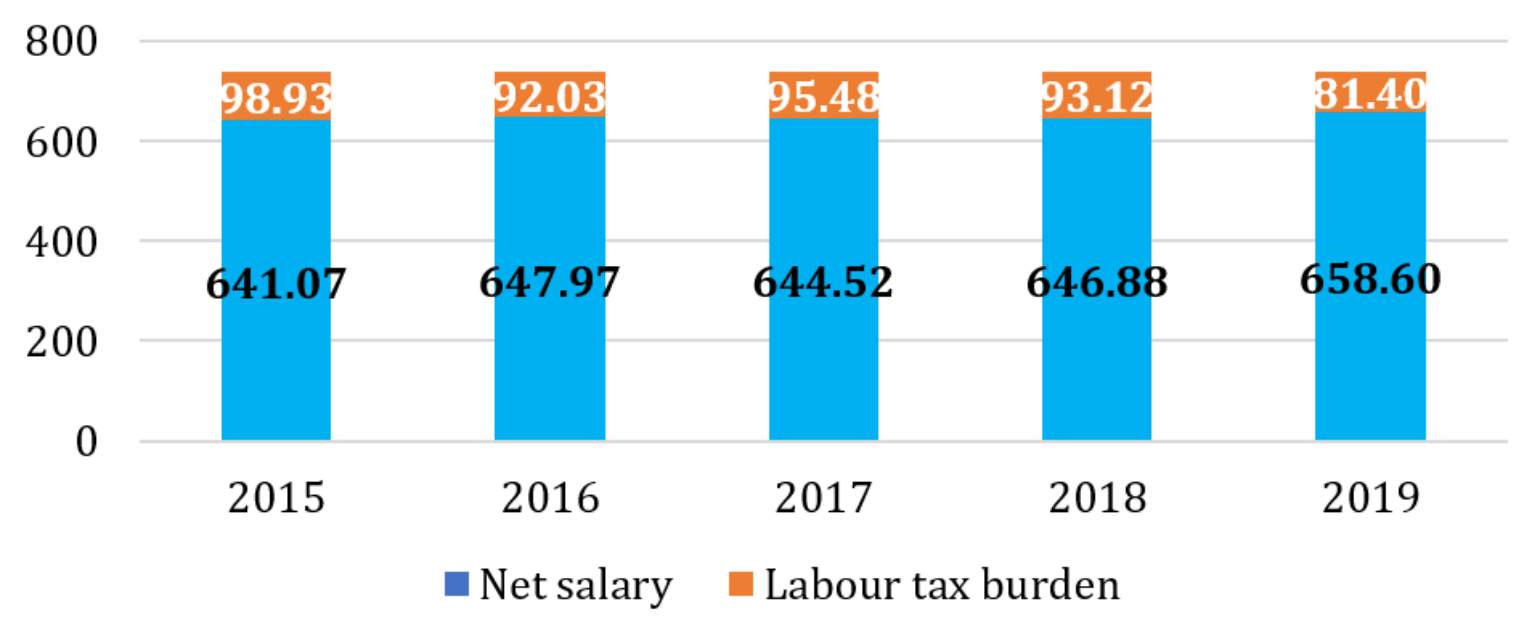

Fig. 1. Calculation of employee X`s net salary and labour tax burden in 2015-2019, EUR (calculations of the authors) 
According to the calculations, it was concluded that during the five-year period, changing both labour tax rates and applicable benefits, the net salary of employee $\mathrm{X}$ increased by 17.53 EUR or $2.73 \%$ and the labour tax burden decreased by 17.53 EUR or $17.72 \%$.

Over a five-year period, the net salary of employee $\mathrm{X}$ and the calculated labour tax burden were mainly affected by the changes in the relief applicable to gross salary. To verify this statement, was performed the calculation of employee X's net salary, taking into account the following additional conditions, in addition to the above: the benefits applicable to gross salary remain unchanged at the 2015 level, but the labour tax burden changes in accordance with the legislation of the Republic of Latvia. (Fig.2)

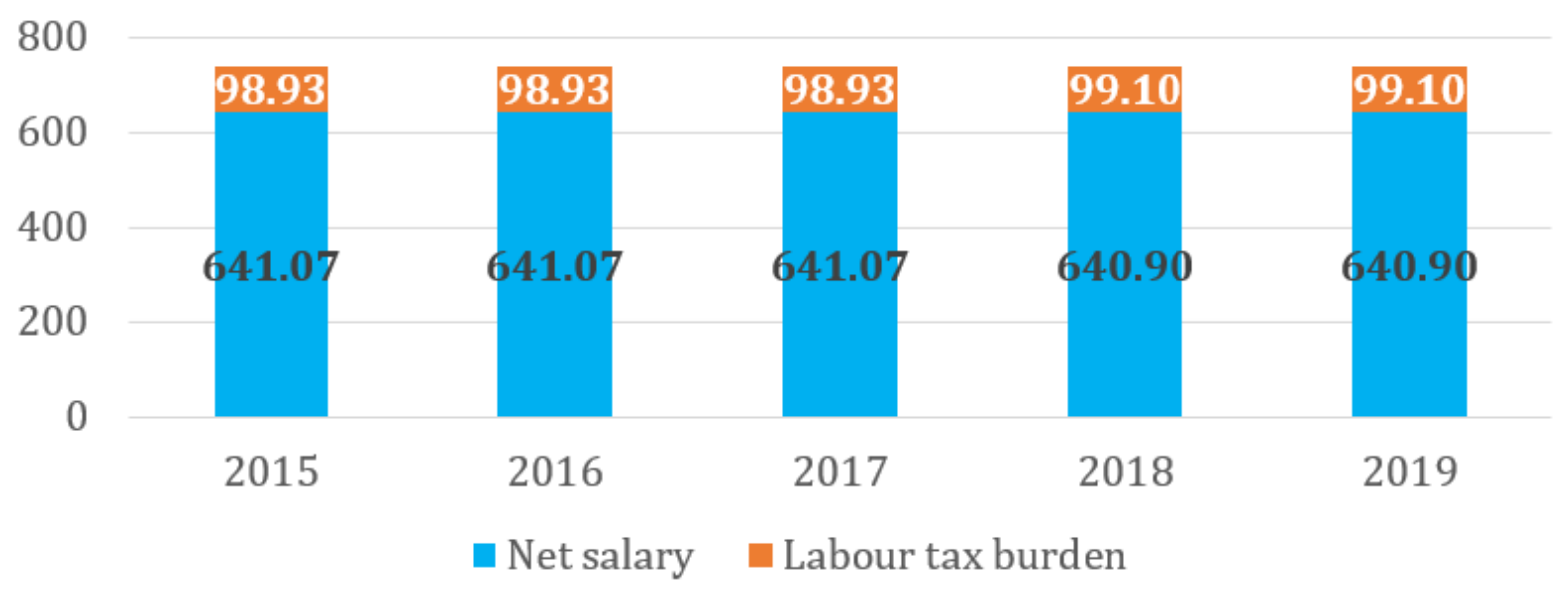

Fig. 2. Changes of the net salary and labour tax burden of employee $X$ `s if income tax relief applicable to gross salary remain unchanged, 2015-2019, EUR (calculations of the authors)

The data of Fig 2 shows that if income tax relief applicable to gross salary remain unchanged at the level of 2015, then the net salary of employee $X^{\prime}$ decrease by 0.27 EUR or $0.04 \%$ and the labour tax burden increase by 0.19 EUR or $0.18 \%$ in $2015-2019$. Trends in these changes confirm that the labour tax burden does not affect the standard of living of the inhabitants (disposable income or material well-being).

Thus, the hypothesis that the implemented changes in the labour tax burden in Latvia have been successful and there was an increase in the standard of living of the inhabitants in Latvia can be partially confirmed. This can be explained by the fact that the labour tax burden does not affect net salary growth in the short run, however it is driven by the application and increase of income tax relief. It should be noted that increase of the mandatory state social insurance contributions increases the social insurance budget of the employee, providing more support in the case of a 
social insurance event, which ensures an increase of standard of living in the long run.

\section{Conclusions and suggestions}

1. The standard of living is one of the most important aspects in the life of an individual, and the disposable income of the inhabitants and its changes is one of the characteristic indicators of the standard of living. The experts, assessing the indicators of the standard of living of the inhabitants, recognized the level of disposable income of households as the most important indicator.

2. The labour tax burden in Latvia consists of such tax payments as mandatory state social insurance contributions, solidarity tax and personal income tax.

3. The experts, evaluating the measures implemented by the government of Latvia and local governments to increase the standard of living of the inhabitants, recognized the availability of education as the most important measure. The experts assessed the reduction and increase of the labour tax burden as the third most important measure implemented by the government of Latvia and local governments to increase the standard of living of the inhabitants.

4. Employees employed in Latvia must use the possibilities of gross salary income tax relief, thus promoting the increase of their net salary, considering the role of applicable gross salary income tax relief in reducing the labour tax burden.

5. To increase the standard of living of the inhabitants of Latvia in the short and long term, the government of Latvia must emphasize its attention to the general growth of the national economy - from raising the territorial development index in the statistical regions of Latvia to supporting business in all sectors.

6. The government of Latvia and local governments should implement measures aimed at raising the long-term standard of living of the inhabitants and gaining material benefits for the majority of the inhabitants in the future, such as ensuring access of education by providing more budget study places that would lead to a higher share of qualified specialists in the labour market in Latvia.

\section{References}

1. Anča, G., Barisa, L., Cimdinšs, P., et al. (2006). Tautas attīstība. Rīga: Jumava \& Sorosa fonds Latvija \& UNDP.

2. Bērziṇa, K., Bērziṇš, G., Blunavs, G., et al. (2008) Tūrisma un viesmīlības terminu skaidrojošā vārdnīca: vārdnīca. Rīga: Latvijas Republikas Ekonomikas ministrija. 
3. Blundell, R., Joyce, R., Norris Keiller, A. and Ziliak, J. (2018). Income Inequality and the Labour Market in Britain and the US. Journal of Public Economics, 162, 48-63.

4. Busler, M. (2013) Income tax policy: is a single rate tax optimum for long-term economic growth? World Journal of Entrepreneurship, Management and Sustainable Development, 9(4), 246-254.

5. CSP datubāze (2020). Strādājošo mēneša vidējā darba samaksa pa mēnešiem. Retrieved

from https://data1.csb.gov.lv/pxweb/lv/sociala/sociala dsamaksa isterm/DS010m. $\mathrm{px} /$ table/tableViewLayout1/

6. Finanšu ministrija. (2017). Pielikums "Esošās situācijas raksturojums". Retrieved from https://cutt.ly/eyXpufL

7. Grēviṇa, R., Kaža, V., Kroders, K., u.c. (2000) Ekonomikas skaidrojošā vārdnīca: 4478 termini ar tulkojumu anglı, vācu, franču, krievu valodā. Rīga: Zinātne.

8. iFinanses. (2019) Nodoklu likmes. Retrieved from https://ifinanses.lv/lapas/nodoklu-likmes

9. Investopedia.com (2019) Standard of Living. Retrieved from https://www.investopedia.com/terms/s/standard-of-living.asp

10. Jarockis, A. (2015., 24.sep.) Solidaritātes nodoklis tiek ieviests visas sabiedrības labklājības interesēs. Retrieved from https://www.vienotiba.lv/jaunumi/zinas/solidaritates-nodoklis-tiek-ieviestsvisas-sabiedribas-labklajibas-intereses/

11. Kendall, M.G. (1955) Rank Correlation Methods. New York: Hafner Publishing Co.

12. Ketners, K., Titova, S. (2009) Nodoklu politika Eiropas Savienības vidē. Rìga: Banku augstskolas biznesa un finanšu pētniecības centrs.

13. Nadirova, O., Aliyevb, K. (2016) Motivation to work, labor income taxes and life satisfaction: Hungary, Estonia, Continental Europe and the United States. Procedia Economics and Finance, 39, 373 - 379.

14. Puzule, A. (2019) Iedzīvotāju ienākuma nodokḷa piemērošanas darba samaksai izpēte Baltijas valstīs. SOCIETY. INTEGRATION. EDUCATION. Proceedings of the International Scientific Conference, VI, 654-664.

15. Solidaritātes nodokla likums. (2015., 30.nov.) Latvijas Republikas likums. Retrieved from http://m.likumi.lv/doc.php?id=278636

16. Stratēgiiskās analīzes komisija. (2006) Dzìves kvalitāte Latvijā. Rīga: Zinātne.

17. Varvazovska, P., Prasilova, M. (2015) Households' Level of Living in the Capital of Czech Republic. Procedia Economics and Finance, 26, 1074-1079.

18. Winiarcyuk-Razniak, A. and Razniak, P. (2011) Regional Differences in the Standard of Living in Poland (Based on Selected Indices). Procedia Social and Behavioral Science, 19, 31-36. 